\title{
Dampak Penggunaan Gadget terhadap Hasil Belajar dan Minat Belajar Siswa Sekolah Dasar
}

\section{Nikmawati ${ }^{*}$, Henry Suryo Bintoro ${ }^{2}$, Santoso ${ }^{3}$}

1,3 Prodi Pendidikan Guru Sekolah Dasar, Universitas Muria Kudus, Kudus, Indonesia

${ }_{2}^{2}$ Pendidikan Matematika, Universitas Muria Kudus, Kudus, Indonesia

\section{ARTICLE INFO}

Article history:

Received August 27, 2021

Revised August 28, 2021

Accepted September 30, 2021

Available online December 25, 2021

Kata Kunci

Penggunaan Gadget, Hasil Belajar, Minat Belajar

\section{Keywords:}

Use Of Gadget, Learning Outcomes, Interest in Learning

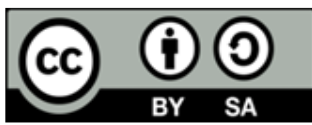

This is an open access article under the CC BY-SA license.

Copyright (c) 2021 by Author. Published by Universitas Pendidikan Ganesha.

\begin{abstract}
A B S T R A K
Gadget merupakan alat elektronik yang digunakan sebagai media informasi, media belajar, dan sebagai hiburan. Manfaat gadget lainnya yaitu dapat tersambung dengan internet dan siswa sudah mengenal fungsi internet. Hal ini mengakibatkan banyak siswa yang menyalahgunakan penggunaan internet untuk hal negatif, sehingga siswa harus selalu dalam pengawasan orang tua. Tujuan penelitian ini adalah untuk menganalisis pengaruh penggunaan gadget terhadap minat belajar siswa kelas $\mathrm{V}$ sekolah dasar. Jenis penelitian yang digunakan dalam penelitian ini adalah kuantitatif deskriptif dengan menggunakan metode noneksperimen. Teknik penentuan sampel yang digunakan adalah teknik Non Probabiliti Sampling dan menggunakan sampling jenuh. Teknik pengumpulan data meliputi observasi, wawancara, angket, dan dokumentasi. Penelitian ini dilaksanakan dengan subjek penelitian 24 orang siswa dan guru kelas 5. Hasil penelitian menunjukkan bahwa penggunaan gadget tidak berpengaruh secara signifikan terhadap hasil belajar siswa. Pernyataan ini dibuktikan dari hasil penghitungan analisis regresi sederhana dengan perolehan thitung < t-tabel $(0,539<2,06)$ dan signifikansi $0,596>0,05$. Selanjutnya, penggunaan gadget berpengaruh secara signifikan terhadap minat belajar siswa. Pernyataan ini dibuktikan dengan perolehan t-hitung $>$ t-tabel $(5,044>2,063)$ dan signifikansinya 0,000 $<0,05$. Berdasarkan hasil tersebut, dapat disimpulkan bahwa penggunaan gadget tidak berpengaruh secara signifikan terhadap hasil belajar siswa dan berpengaruh secara signifikan terhadap minat belajar siswa sekolah dasar.
\end{abstract}

\begin{abstract}
A B S T R A C T
Gadgets are electronic devices that are used as information media, learning media, and entertainment. Another benefit of gadgets is that they can be connected to the internet and students are familiar with the functions of the internet. So that many students abuse the use of the internet for negative things, so students must always be under parental supervision. The purpose of this study was to analyze the effect of using gadgets on the learning interest of fifth-grade elementary school students. The type of research used in this research is descriptive quantitative using non-experimental methods. The sampling technique used is the Non-Probability Sampling technique and uses saturated sampling. Data collection techniques include observation, interviews, questionnaires, and documentation. This research was conducted with 24 students and fithth-grade teachers as research subjects. The results showed that the use of gadgets had no significant effect on student learning outcomes. This statement is evidenced by the results of simple regression analysis with the acquisition of $t$-count $<t$-table $(0.539<2.06)$ and a significance of $0.596>0.05$. Furthermore, the use of gadgets has a significant effect on students' interest in learning. This statement is evidenced by the acquisition of $t$-count $>t$-table $(5.044>2.063)$ and the significance is $0.000<0.05$. Based on these results, it can be concluded that the use of gadgets has no significant effect on student learning outcomes and significantly affects the learning interest of elementary school students.
\end{abstract}




\section{PENDAHULUAN}

Kemajuan zaman di bidang ilmu teknologi semakin berkembang (Azizul et al., 2020; Lestari, 2018). Teknologi yang sangat populer di era globalisasi ini adalah gadget (Dewi, 2019; Patricia, 2020). Gadget dahulu hanya digunakan oleh kalangan menengah ke atas. Namun, sekarang gadget tidak hanya digunakan oleh orang-orang penting, tetapi juga digunakan anak-anak usia sekolah (Pankaj S. Parsania, 2015; Suhana, 2018). Penggunaan gadget dalam dunia pendidikan merupakan sebuah permasalahan yang perlu dikaji secara mendalam karena dalam pikiran sepertinya gadget hanya berguna untuk menyampaikan Short Message service (SMS), mendengarkan musik, menonton tayangan audiovisual, dan game (Angga et al., 2020). Gadget merupakan sebuah perangkat atau alat elektronik yang memiliki fungsi khusus dalam penggunaannya yang telah mengubah perilaku komunikasi manusia dengan menembus ruang dan waktu (Hudaya, 2018; Nizar \& Hajaroh, 2019). Kini gadget bukan lagi sekadar alat berkomunikasi, tetapi gadget juga merupakan alat untuk menghibur dengan suara, tulisan, gambar dan video. Gadget merupakan suatu istilah yang digunakan dalam menyebut beberapa macam jenis alat teknologi yang sifatnya semakin berkembang pesat dan memiliki fungsi khusus (Arwansyah \& Wahyuni, 2020; Hudaya, 2018). Contoh dari gadget yaitu smartphone, I phone, computer, laptop, dan tab. Berdasarkan penelitian terdahulu diketahui bahwa terjadi peningkatan penggunaan media dan gadget pada anak yaitu 38\% pada tahun 2011 dan meningkat menjadi 72\% pada tahun 2013 (Nurhalipah et al., 2020). Salah satu faktor yang mendasari meningkatnya persentase anak yang menggunakan gadget yaitu karena semakin berkembangnya teknologi. Seiring berkembangnya teknologi, maka gadget tampil dengan system touch screen yang membuat siapa pun lebih mudah untuk menggunakannya, terutama anak kecil yang belum bisa membaca sekalipun, seperti penggunaan smartphone.

Pada dasarnya penggunaan teknologi gadget pada saat ini memiliki dampak positif dan negatif bagi anak, di antaranya dalam pembentukan pola pikir anak, yaitu dapat membantu anak dalam mengatur kecepatan bermainnya, mengolah strategi dan analisis dalam permainan, dan membantu anak dalam meningkatkan kemampuan otak kanan selama dalam pengawasan yang baik oleh orang tua (Damayanti et al., 2020; Nurhalipah et al., 2020). Akan tetapi, dari beberapa dampak positif tadi, jika diteliti lebih lanjut maka faktor dominan lebih ke arah dampak negatif yang berpengaruh terhadap perkembangan anak. Anakanak biasanya mendapatkan gadget dari kedua orang tuanya sebagai hiburan. Awalnya penggunaan pertama hanya diisi dengan fitur audio seperti musik supaya anak tidak jenuh dan menjadi media hiburan untuk anak-anaknya. Namun, lama kelamaan anak-anak biasanya bosan dengan konten atau fitur yang ada, sehingga anak-anak luput dari pengawasan orang tua. Anak-anak akan memanfaatkan gadget untuk kepentingan bermain game, menonton youtube, dan lain sebagainya yang menyenangkan daripada komunikasi (Nizar \& Hajaroh, 2019). Anak-anak menjadi terlena dengan gadget dan tidak peduli lagi dengan belajarnya.

Belajar adalah proses perubahan dalam manusia dan bentuk perubahan itu diperlihatkan dalam peningkatan kualitas dan kuantitas tingkah laku seperti peningkatan kecakapan, pengetahuan, sikap, kebiasaan, pemahaman, keterampilan, daya pikir, dan kemampuan-kemampuan yang lain (Harahap \& Ely, 2018; Sumiatun, 2013). Belajar juga dapat dikatakan akibat dari adanya interaksi dan respon. Seseorang dianggap telah belajar sesuatu jika ia dapat menunjukkan pencapaian dalam dirinya. Misalnya, seorang peserta didik telah mampu untuk membaca dan menulis, maka peserta didik itu dapat dikatakan telah berhasil dalam belajarnya. Perubahan perilaku peserta didik dari yang tidak dapat membaca dan menulis sampai akhirnya dapat membaca dan menulis itu merupakan hasil dari belajar (Handayani, 2017; Puspitasari, 2019). Hasil belajar adalah perubahan yang terjadi pada diri peserta didik secara pengetahuan, sikap dan keterampilan juga perubahan yang ada pada diri peserta didik akan menimbulkan peningkatan dan pengembangan yang lebih baik dan hasil dari suatu interkasi dari tindakan belajar dan tindak mengajar (Nurdin et al., 2019; Yuanta, 2019). Hasil belajar adalah hasil yang dicapai individu setelah mengalami proses adaptasi dengan lingkungannya maupun pengalamannya (belajar). Siswa akan memperoleh hasil belajar yang maksimal apabila siswa memiliki kesungguhan dalam belajarnya. Kegiatan belajar yang dilakukan baik di sekolah maupun di rumah harus berdasarkan dari keinginan yang timbul dari dalam dirinya tertarik untuk belajar, ketertarikan yang dimaksud adalah minat (Hudaya, 2018). Anak yang memiliki minat terhadap suatu hal yaitu belajar maka anak akan berusaha semaksimal mungkin untuk mencapai tujuan dari kegiatan belajarnya. Sejalan dengan hal tersebut, faktor yang mendorong hasil belajar adalah minat (Angga et al., 2020).

Minat belajar merupakan salah satu peranan penting dalam menentukan prestasi belajar anak. Siswa yang memiliki minat belajar akan memusatkan perhatiannya pada pembelajaran. Dalam kegiatan belajar, minat besar pengaruhnya terhadap aktivitas belajar (Arwansyah \& Wahyuni, 2020). Bila seorang siswa tidak memiliki minat dan perhatian yang besar terhadap mata pembelajaran yang dipelajari maka sulit diharapkan anak tersebut akan tekun dan memperoleh prestasi belajar yang baik pada mata pelajaran tersebut. Sebaliknya, apabila siswa belajar dengan minat dan perhatian besar terhadap mata pelajaran yang 
dipelajari, siswa yang menggunakan gadget untuk chattingan, mengakses media sosial, bermain game, dan mengakses hal-hal lain yang tidak ada hubungannya dengan pelajaran sekolah. Hal ini tentu saja membuat para siswa lupa waktu dalam menggunakan gadget tersebut dan membuat mereka lupa akan kewajiban utama mereka sebagai seorang pelajar yaitu belajar. Minat belajar siswa, dapat diukur dengan beberapa indikator. Rahmawati, 2017 indikator-indikator minat belajar yaitu, perasaan senang, adanya rasa ketertarikan, keterlibatan dalam belajar, rajin belajar dan mengerjakan tugas, tekun dan disiplin dalam belajar serta memiliki jadwal belajar. Tujuan penelitian ini adalah untuk menganalisis pengaruh penggunaan gadget terhadap minat belajar siswa kelas V sekolah dasar.

\section{METODE}

Penelitian ini menggunakan pendekatan kuantitatif deskriptif (Sugiyono, 2014). Dijelaskan bahwa penelitian kuantitatif deskriptif adalah penelitian yang bertujuan menjelaskan fenomena yang ada dengan menggunakan angka-angka untuk mencadarkan karakteristik individu atau kelompok. Pada penelitian ini, peneliti menggunakan metode non eksperimen. Metode non eksperimen adalah penelitian yang observasinya dilakukan terhadap sejumlah ciri (variabel) subjek penelitian menurut keadaan apa adanya, tanpa ada manipulasi (intervensi) peneliti. Dalam penelitian ini populasinya adalah siswa kelas 5 SDIT Faidlurrahman Kecamatan Dawe Kabupaten Kudus. Peneliti menggunaakn Teknik Non Probabiliti Sampling dan sampel yang digunakan adalah Sampling Jenuh karena seluruh anggota populasi dijadikan sebagai sampel. Subjek penelitian ini adalah siswa kelas 5 SDIT Faidlurrahman yang berjumlah 24 siswa. Teknik pengumpulan data yang digunakan adalah, wawancara, observasi, dokumentasi, dan angket. Serta isntrumen penelitiannya adalah wawancara, observasi, dokumentasi, dan angket. Analisis data yang digunakan adalah Uji Normalitas, Uji Linieritas, dan Uji Hipotesis yang digunakan adalah Uji Korelasi dan Uji Regresi sederhana. Data hasil penelitian terdiri dari satu variable bebas yaitu penggunaan gadget $(\mathrm{x})$ dan dua variable terikat berupa hasil belajar $\left(\mathrm{Y}_{1}\right)$ dan minat belajar $\left(\mathrm{Y}_{2}\right)$. Data yang disajikan oleh peneliti berupa skor angket penggunaan gadget, skor angket minat belajar, dan hasil belajar diperoleh dari nilai murni ulangan tengah semester siswa kelas 5 yang digunakan sebagai sampel penelitian. Penelitian ini dialaksanakan di SDIT Faidlurrahman Kecamatan Dawe Kabupaten Kudus.

\section{HASIL DAN PEMBAHASAN}

Hasil

\section{Uji Normalitas}

Sebelum diadakan pengujian hipotesis, hal yang dilakukan terlebih dahulu adalah ujian prasyarat analisis data yang meliputi uji normalitas. Uji normalitas data dilakukan untuk mengetahui apakah sebaran data dalam penelitian berdistribusi normal atau tidak. Berdasarkan hasil analisis data, dapat diketahui uji normalitas kolmogorov smirnov penggunaan gadget menunjukkan nilai Kolmogorov-Smirnov Z hasil 0,816 dengan sig. 0,518. Sesuai dengan pengambilan keputusanyang sudah ditetapkan, jika nilai signifikasi lebih besar dari 0,05 maka dapat dipastikan bahwa data tersebut normal. Dengan hasil uji normalitas yang terdapat pada tabel sebesar $0,518>0,05$, maka hal ini menunjukkan bahwa data penggunaan gadget berdistribusi normal. Uji normalitas kolmogorov smirnov hasil belajar menunjukkan nilai KolmogorovSmirnov Z hasil 0,877 dengan sig. 0,425. Sesuai dengan pengambilan keputusan yang sudah ditetapkan, jika nilai signifikasi lebih besar dari 0,05 maka dapat dipastikan bahwa data tersebut normal. Dengan hasil uji normalitas yang terdapat pada tabel sebesar 0,425 >0,05, maka hal ini menunjukkan bahwa data hasil belajar berdistribusi normal. Uji normalitas kolmogorov smirnov minat belajar menunjukkan nilai Kolmogorov-Smirnov Z hasil 0,441 dengan sig. 0,990. Sesuai dengan pengambilan keputusanyang sudah ditetapkan, jika nilai signifikasi lebih besar dari 0,05 maka dapat dipastikan bahwa data tersebut normal. Dengan hasil uji normalitas yang terdapat pada tabel sebesar $0,990>0,05$, maka hal ini menunjukkan bahwa data minat belajar berdistribusi normal.

\section{Uji Linearitas}

Hasil uji linieritas penggunaan gadget dengan hasil belajar bahwa pada kolon Sig. baris Deviation from linierity diketahui nilai signifikansi sebesar 0,924. Hasil ini menunjukkan bahwa variabel penggunaan gadget dengan hasil belajar memiliki hubungan yang linier, karena nilai signifikansi lebih dari 0,05. Sig. pada tabel Coefficients diketahui bahwa nilai signifikansinya sebesar 0,596. Karena nilai signifikansi lebih besar dari $0,05(0,596>0,05)$, maka dapat disimpulkan bahwa H01 diterima dan Ha1 ditolak. Dapat disimpulkan bahwa tidak terdapat pengaruh yang signifikan antara penggunaan gadget terhadap hasil belajar pada siswa kelas V SD SDIT Faidlurrahman Kudus. Berdasarkan perhitungan hasil uji linieritas penggunaan gadget dengan hasil belajar bahwa pada kolon Sig. baris Deviation from linierity diketahui nilai 
signifikansi sebesar 0,924. Hasil ini menunjukkan bahwa variabel penggunaan gadget dengan hasil belajar memiliki hubungan yang linier, karena nilai signifikansi lebih dari 0,05. Berdasarkan kolom Sig. pada tabel Coefficients diketahui bahwa nilai signifikansinya sebesar 0,596. Karena nilai signifikansi lebih besar dari $0,05(0,596>0,05)$, maka dapat disimpulkan bahwa tidak terdapat pengaruh yang signifikan antara penggunaan gadget terhadap hasil belajar pada siswa kelas V SD SDIT Faidlurrahman Kudus. Berdasarkan hasil uji linieritas penggunaan gadget dengan minat belajar bahwa pada kolon Sig. baris Deviation from linierity diketahui nilai signifikansi sebesar 0,311. Hasil ini menunjukkan bahwa variabel penggunaan gadget dengan minat belajar memiliki hubungan yang linier, karena nilai signifikansi lebih dari 0,05. Berdasarkan kolom Sig. pada tabel Coefficients diketahui bahwa nilai signifikansinya sebesar 0,000. Karena nilai signifikansi lebih kecil dari $0,05(0,000<0,05)$, maka dapat disimpulkan terdapat pengaruh yang signifikan antara penggunaan gadget terhadap minat belajar pada siswa kelas V SDIT Faidlurrahman, kecamatan Dawe, Kabupaten Kudus.

\section{Hasil Analisis Regresi}

Penggunaan gadget tidak berpengaruh positif dan signifikan dengan hasil belajar. Pernyataan ini dibuktikan dari hasil penghitungan analisis regresi sederhana dengan perolehan thitung $<$ ttabel $(0,539<$ 2,06) dan signifikansinya 0,596 >0,05, berarti Ho diterima dan Ha di tolak, yang berarti penggunaan gadget tidak berpengaruh positif dan signifikan dengan hasil belajar. Karena besarnya pengaruh penggunaan gadget dengan hasil belajar tergolong sangat rendah, nilai korelasi seerhana yang diperoleh sebesar 0,114 dan berada pada rentang 0,100 - 0,299. Namun arah hubungan adalah positif, karena nilai R positif, berarti semakin tinggi penggunaan gadget, maka semakin meningkat hasil belajar siswa. Selain itu, diperoleh angka $\mathrm{R}^{2}$ ( $R$ Square) sebesar 0,013, artinya persentase sumbangan pengaruh variabel penggunaan gadget terhadap hasil belajar sebesar 0,013 x 100\% = 1,3\%. Penggunan gadget berpengaruh positif dan signifikan terhadao minat belajar siswa. Pernyataan ini dibuktikan dengan perolehan t-hitung $>$ t-tabel (5,044 > 2,063) dan signifikansinya 0,000 < 0,05, berarti $\mathrm{Ho}$ ditolak, yang berarti penggunaan gadget berpengaruh secara signifikan dengan minat belajar. Nilai korelasi sederhana variable pengguna an gagdet dengan minat belajar sebesar 0,732 berada diantara $0,7-0,899$, sehingga hubungan antara kedua variabel tergolong tinggi. Arah hubungan adalah positif, karena nilai R positif, berarti semakin tinggi penggunaan gadget, semakin meningkat minatsiswauntuk beajar. Selain itu, diperoleh angka $\mathrm{R}^{2}(R$ Square) sebesar 0,307, artinya persentase sumbangan pengaruh variabel penggunaan gadget terhadap minat belajar siswa sebesar 0,536 x 100\% = 53,6\%. Penggunaan gadget memberikan kontribusi yang positif terhadap minat belajar siswa, dimana penggunaan gadget yang positif akan membuat siswa proaktif dalam aktivitas belajarnya dengan cara mandiri atas dasar motivasinya sendiri tidak tergantung pada orang lain.

\section{Pembahasan}

\section{Pengaruh Penggunaan Gadget terhadap hasil Belajar}

Penggunaan gadget tidak berpengaruh terhadap hasil belajar. Hal ini didapat hasil angket tentang Handphone membuat saya malas belajar sebagian besar siswa menjawab setuju dan Handphone memengaruhi nilai ujian saya juga sebagian besar siswa menjawab setuju. Hal ini yang menjadikan bahwa penggunaan gadget justru menjadikan siswa malas belajar dan nilai ujian yang diperolehnya semakin menurun (Damayanti et al., 2020; Nurhalipah et al., 2020). Perkembangan budaya yang sangat pesat diikuti dengan kemajuan teknologi yang serba canggih. Bila tidak mampu memanfaatkan dengan positif terlebih untuk kebutuhan belajar, akan menjadikan hal yang mengganggu kegiatan belajar. Hal ini tidak terlepas dari teori Balitbang tentang fungsi gadget antara lain: 1) sebagai alat komunikasi agar tetap terhubung dengan teman ataupun keluarga, 2) sebagai penunjang bisnis, 3) sebagai pengubah batas sosial masyarakat, dan 4) sebagai alat penghilang stres. Jika intensitasnya tidak diikuti dengan penggunaan yang tepat, khususnya untuk siswa yang masih duduk di bangku SD, hal tersebut dapat memengaruhi minat belajarnya. Hal ini dapat mengganggu prestasi belajar di sekolah. Kemajuan teknologi seharusnya dapat dimanfaatkan untuk mendapatkan informasi yang lebih luas, misalnya melalui internet siswa dapat mencari bahan atau materi pelajaran yang siswa tersebut kurang paham ketika belajar di sekolah. Hal ini sesuai dengan pendapat yang menyatakan bahwa penggunaan gadget dapat mendukung kegiatan belajar dengan salah satunya menggunakan browser untuk mencari sumber pelajaran selain buku. (Suhardi et al., 2019). Gadget memiliki manfaat sebagai sarana belajar anak. Manfatnya antara lain untuk belajar berbicara dengan cara memperlihatkan video perkenalan yang selanjutnya bisa ditirukan oleh anak, belajar menghitung, mengenal huruf, mengenal binatang, dan lain sebagainya. Belajar dengan menggunakan gadget tentunya akan lebih menarik karena terdapat banyak fitur yang menarik yang dapat dimanfaatkan untuk kegiatan belajar. Siswa akan bersemangat belajar ketika dirinya merasa senang dan tertarik, akan lebih termotivasi untuk terus belajar (Harahap \& Ely, 2018; Hudaya, 2018). 
Selain memiliki dampak positif ternyata gadget juga memiliki dampak negatif antara lain adalah seperti kecanduan game online pada anak sekolah dasar, membuat anak lambat dalam memahami pelajaran, dan juga bisa menyebabkan resiko terkena radiasi karena terlalu sering main gadget dan terlalu dekat dengan mata. Dengan adanya dampak negatif dalam penggunaan gadget terhadap anak SD, maka ada juga solusi untuk mencegah agar tidak terjadi hal-hal yang tidak diinginkan. Contohnya, menghindari memperkenalkan gadget pada anak SD, memberikan contoh yang baik kepada anak, dan jangan terlalu memanjakan anak. Orang tua juga sangat berperan penting dalam pengawasan anak pada saat di rumah. Contohnya, orang tua selalu mendampingi anak pada saat bermain gadget dan membatasi waktu anak dalam bermain game, agar anak tau waktu untuk bermain dan belajar, selalu mengajarkan anak untuk penggunaan gadget yang benar adalah sesuai kebutuhannya saja, selalu memastikan bahwa anak menggunakan gadget untuk hal-hal yang positif saja, misalnya untuk mencari materi di internet. Guru juga sangat berperan penting dalam pengawasan anak pada saat di sekolah. Misalnya, guru memilihkan game yang baik untuk anak (game yang bersifat mendidik), menentukan durasi pada saat bermain game, atau mengajak anak untuk beraktivitas tanpa menggunakan gadget

\section{Pengaruh Penggunaan Gadget terhadap Minat Belajar}

Di era 4.0 seperti sekarang ini minat belajar pada anak-anak semakin menurun terlebih karena adanya pengaruh teknologi informasi yang sangat berkembang pesat termasuk gadget. Gadget berpengaruh pada anak-anak dalam proses berinteraksi pada ruang lingkup sekolahnya maupun di rumah, terutama pada masa pandemi ini. Semua proses belajar mengajar dilakukan secara online/durring yang menuntut setiap guru maupun siswa melakukan pembelajaran menggunakan gadget atau komputer. Gadget dapat memudahkan anak-anak dalam proses belajarnya, tetapi tidak menutup kemungkinan bahwa gadget juga dapat menghambat anak-anak untuk belajar. Para orang tua agar selalu mendampingi anak-anak dalam menggunakan gadget. Jika tanpa didampingi oleh orang tua, anak-anak akan lebih senang bermain game atau media social dibandingkan belajar atau mengerjaka tugas sekolah. Hasil penelitian tersebut menunjukkan bahwa penggunaan gadget berpengaruh terhadap minat belajar. Dengan adanya penggunaan gadget, anak-anak diharapkan mampu mempergunakan sesuai batasan waktu yang sesuai dengan durasi penggunaan gadget, yaitu penggunaan tinggi yaitu pada intensitas penggunaan lebih dari 3 jam dalam sehari, penggunaan sedang yaitu pada intensitas penggunaan sekitar 3 jam dalam sehari, penggunaan rendah yaitu pada intensitas penggunaan kurang dari 3 jam dalam sehari. Jika anak-anak mampu mempergunakannya dengan baik maka tidak adan mengganggu kosentrasi belajar mereka saat berada di sekolah.

\section{SIMPULAN}

Berdasarkan hasil pengujian dari penelitian ini maka dapat disimpulan sebagai berikut. Penggunaan gadget tidak berpengaruh secara signifikan terhadap hasil belajar siswa kelas V SDIT Faidlurrahman Kecamatan Dawe, Kabupaten Kudus., Penggunaan gadget berpengaruh secara signifikan terhadap minat belajar siswa kelas V SDIT Faidlurrahman Kecamatan Dawe, Kabupaten Kudus.

\section{DAFTAR RUJUKAN}

Angga, P. M. W., Sudarma, I. K., \& Suartama, I. K. (2020). E-Komik Pendidikan untuk Membentuk Karakter dan Meningkatkan Hasil Belajar Siswa Kelas V pada Mata Pelajaran Bahasa Indonesia. Jurnal Edutech Undiksha, 8(2), 93. https://doi.org/10.23887/jeu.v8i2.28920.

Arwansyah, A., \& Wahyuni, S. (2020). Pengaruh Penggunaan Smartphone dan Minat Belajar terhadap Prestasi Belajar Siswa pada Mata Pelajaran Kewirausahaan SMK Al-Wasliyah Pasar Senenmedan TA 2018/2019. Jurnal Ekodik: Ekonomi Pendidikan, 7(1), 31-44. https://jurnal.unimed.ac.id/2012/index.php/ekodik/article/view/16446.

Azizul, A., Riski, W. Y., Fitriyani, D. I., \& Sari, I. N. (2020). Pengembangan Bahan Ajar Komik Digital pada Mater Gerak. Vox Edokasi: Jurnal Ilmiah Ilmu Pendidikan, 11(2). https://doi.org/10.31932/ve.v11i2.829.

Damayanti, E., Ahmad, A., \& Bara, A. (2020). Dampak Negatif Penggunaan Gadget Berdasarkan Aspek Perkembangan Anak di Sorowako. Martabat J. Peremp. Dan Anak, 4(1), 1-22. http://178.128.61.209/index.php/martabat/article/view/2948.

Dewi, E. (2019). Potret Pendidikan di Era Globalisasi Teknosentrisme dan Proses Dehumanisasi. Sukma: Jurnal Pendidikan, 3(1), 93-116. https://doi.org/10.32533/03105.2019.

Handayani, D. (2017). Pengaruh Perhatian Orang Tua dan Konsep Diri Siswa terhadap Hasil Belajar Matematika Siswa. Jurnal Pendidikan Dasar, 8(1). https://doi.org/10. 21009/JPD. 
Harahap, R. S., \& Ely, R. (2018). Pengaruh Penggunaan Gadget terhadap Hasil Belajar Siswa Kelas V SD Negeri 12 Banda Aceh. Jurnal Ilmiah Mahasiswa Pendidikan Guru Sekolah Dasar, 3(1). http://www.jim.unsyiah.ac.id/pgsd/article/view/8649.

Hudaya, A. (2018). Pengaruh Gadget terhadap Sikap Disiplin dan Minat Belajar Peserta Didik. Research and Development Journal of Education, 4(2). https: / /doi.org/10.30998/rdje.v4i2.3380.

Lestari, S. (2018). Peran Teknologi dalam Pendidikan di Era Globalisasi. Edureligia, 2(2), 94-100.

Nizar, A., \& Hajaroh, S. (2019). Pengaruh Intensitas Penggunaan Game Gadget terhadap Minat Belajar Siswa. El Midad, 11(2), 169-192. https://journal.uinmataram.ac.id/index.php/elmidad/article/view/1901.

Nurdin, E., Ma'aruf, A., Amir, Z., Risnawati, R., Noviarni, N., \& Azmi, M. P. (2019). Pemanfaatan Video Pembelajaran Berbasis Geogebra untuk Meningkatkan Kemampuan Pemahaman Konsep Matematis Siswa SMK. Jurnal Riset Pendidikan Matematika, 6(1), 87-98. https: //doi.org/10.21831/jrpm.v6i1.18421.

Nurhalipah, R., Yustiana, M., Saeni, S., \& Muslih, M. (2020). Pengaruh Gadget terhadap Minat Belajar pada Anak-Anak. Seminar Nasional Informatika (SEMNASIF), 1(1), 172-177.

Pankaj S. Parsania, N. M. C. \& K. C. K. (2015). Information and Communication Technology \& Its Impact in Improving the Teaching and Learning of English Language. International Journal of Computer Science Engineering and Information Technology Research (IJCSEITR), 5(3), 1-6. http: / /www.tjprc.org/view-archives.php?year=2015\&id=14\&jtype=2\&page=2.

Patricia, A. (2020). College Students' Use and Acceptance of Emergency Online Learning Due to COVID-19. International Journal of Educational Research Open, 100011. https://doi.org/10.1016/j.ijedro.2020.100011.

Puspitasari, S. (2019). Upaya Meningkatkan Hasil Belajar IPA dengan Menggunakan Model Pembelajaran Think Pair Share. Jurnal Global Edukasi, 3(1), 55-60. http://jurnal.goretanpena.com/index.php/JGE/article/view/339.

Sugiyono. (2014). Metode Penelitian Pendidikan Pendekatan Kuantitatif, Kualitatif, dan R\&D. Alfabeta.

Suhana, M. (2018). Influence of Gadget Usage on Children's Social-Emotional Development. 169(Icece 2017), 224-227. https://doi.org/10.2991/icece-17.2018.58.

Sumiatun. (2013). Analisis Mutu Pembelajaran Praktikum Kebidanan sebagai Upaya Peningkatan Pencapaian Kompetensi Program Studi Diploma III Kebidanan STIKES Maharani Malang. Jurnal Kebijakan Dan Pengembangan Pendidikan, 1(1), 78-93. https://doi.org/10.22219/jkpp.v1i1.1512.

Yuanta, F. (2019). Pengembangan Media Video Pembelajaran Ilmu Pengetahuan Sosial pada Siswa Sekolah Dasar. Trapsila: Jurnal Pendidikan Dasar, 1(2), 91-100. http://dx.doi.org/10.30742/tpd.v1i02.816. 